\title{
Factors That Would Indicate Diagnosis of Dilating VUR in the Second VCUG of Patients with A Normal First VCUG
}

\author{
Íkinci İşeme Sistoüretrografisinde Dilate Reflüyü İşaret \\ Eden Parametreler
}

Muhammet Irfan Donmez', Ahmet Midhat Elmaci ${ }^{2}$

${ }^{1}$ Konya Training and Research Hospital Pediatric Urology, Konya, Turkey ${ }^{2}$ Konya Dr.Ali Kemal Belviranli Women's Maternity and Children's Hospital - Pediatric Nephrology, Konya, Turkey

Geliş Tarihi/Received: 11 June 2018 Kabul Tarihi/Accepted: 13 November 2018

Address correspondence to: Muhammet Irfan Donmez, MD, FEBU Konya Training and Research Hospital Pediatric Urology, Konya, Turkey

e-mail:m_irfan83@yahoo.com

\section{ORCID}

Muhammet Irfan Donmez

https://orcid.org/0000-0002-2828-7942
Öz

Amaç: Bu çalışmanın amacı ilk işeme sistoüretrografisi (ISUG) normal olup ikinci bir işeme sistografisine gerek duyulan hastalarda dilate vezikoüreteral reflü (VUR) tanısına işaret edebilecek faktörleri tanımlamaktır.

Hastalar ve Yöntem: Hastanemizde takipli hastalardan 2012 - 2017 yılları arasında işeme sistouretrografisi çekilmiş olanlar geriye dönük olarak tarandı. Birden fazla ISUG çekilen hastalar belirlendi. Bu hastala içinden ilk ISUG sonucu normal olup da takipte tekrar iSUG çekilen hastalar çalışmaya dahil edildi. İlk ISUG sonucu normal olmayanlar (vezikoüreteral reflü, posterior uretral valv, divertikül vb.) dışlandı. Dahil edilen gruptaki hastalar yaş, cinsiyet, alt üriner sistem bozukluğu (AÜSB), renal skar varlığı, tekrarlayan idrar yolu enfeksiyonu varlığı, anormal ultrasonografi bulguları (mesane anormallikleri, hidronefroz) ve teknik problem faktörleri (işeme fazı yokluğu vb.) açısından değerlendirildi. İkinci ísUG çekilmesin işaret eden faktörü belirlemek için Mann-Whitney U (sürekli veriler için) ve ki kare (kategorik veriler için) kullanıldı.

Bulgular: Calısmamızda toplamda 25 hastaya ikinci kez ISUG yapıldığı saptandı ( 19 kız, 6 erkek; ortalama yaş $6 \pm 3$ yıl). I'ki ISUG arasında gecen medyan zaman 12 ay (1-72 ay) olarak bulundu. Hastaların 11 'inde ikinci ISUG'da VUR saptanırken bunların 7 tanesi (\%28) dilate VUR ( $\geq$ grade 3 ) idi. Ayrıca bu 7 hastanın 6'sinda VUR çift taraflıydı. Bakılan faktörler arasından yalnızca tekrarlayan idrar yolu enfeksiyonu varlığı dilate VUR saptanması açısından anlamlıydı $(p=0,049)$. Teknik problemlere bağı ı ikinci ISUG çekilmiş olan hastaların hiçbirinde VUR saptanmadı.

Sonuç: IIIk ISUG sonucu normal olmasına rağmen ikinci iSUG çekilmesi gereken vakaların \%28'inde dilate VUR saptanabilmektedir. Tekrarlayan idrar yolu enfeksiyonu varlığı, dilate vezikoüreteral reflüyü işaret edebilecek tek faktör olarak bulunmuştur. Ilk iSUG sonucu normal bulunan hastalarda tekrarlayan idra yolu enfeksiyonu varlığında tekrar ISUG çekilmesi konusunda daha liberal davranılabilir.

Anahtar Kelimeler: İşeme sistoüretrografisi,vezikoüreteral reflü,idrar yolu enfeksiyonu

\section{Abstract}

Aim: The aim of this study is to analyze if there were any factors that would indicate the diagnosis of dilating vesicoureteric reflux (VUR) $(\geq$ grade 3 ) in the second voiding cystourethrogam (VCUG) of children with a normal first VCUG.

Patients and Methods: Patients who underwent VCUG between 2012 and 2017 were retrospectively reviewed. Within the cohort, patients who required more than one VCUG were abstracted and those with an abnormal first VCUG (VUR, posterior urethral valve, diverticula.) were excluded. Factors such as; age, gender, lower urinary tract dysfunction (LUTD), renal scarring, recurrent urinary tract infection, abnormal ultrasonography findings (bladder abnormalities/variable degrees of hydronephrosis), and technica problems (absence of voiding phase) were noted. Mann-Whitney $U$ test was used for continuous variables whereas Chi Square test was used for categorical values.

Results: A total of 25 patients were found to have undergone more than 1 VCUG (19 girls, 6 boys; mean age $6 \pm 3$ years). Median time period between the two VCUGs were 12 months (range $1-72$ months). VUR was detected in 11 patients, while dilating VUR was discovered in 7 patients. Among those, 6 patients were diagnosed with bilateral VUR. Recurrent UTI was found to be the only factor that would indicate dilating VUR in the second VCUG $(p=0,049)$. Interestingly, no VUR was detected in cases that were performed after a first VCUG with inadequate technique.

Conclusion: Recurrent UTI was shown to be the sole factor is associated with indicate the diagnosis of dilating VUR in the second VCUG. In our study, $28 \%$ of patients with a normal first VCUG were shown to have dilating VUR in the second study. Therefore, in recurrent febrile UTI, second VCUG should be considered in patients with a normal previous imaging.

Key words: Voiding cystourethrography,vesicoureteric reflux, urinary tract infection

\section{INTRODUCTION}

Voiding cystourethrography (VCUG) is the gold standard imaging method to identify anatomical and some of the functional problems of the lower urinary tract, particularly vesicoureteric reflux (VUR) (1). In pediatric practice, its role in the evaluation of children
Cite this article as: Donmez MI, Elmaci AM. Factors That Would Indicate Diagnosis of Dilating VUR in the Second VCUG of Patients with A Normal First VCUG. Selcuk Med J 2019;35(3): 149-151
Disclosure: None of the authors has a financial interest in any of the
products, devices, or drugs mentioned in this article. The research was
not sponsored by an outside organization. All authors have agreed to allow
full access to the primary data and to allow the journal to review the data
if requested. 
with urinary tract infection has been well-defined. Both American Association of Urology (AUA) and European Society for Pediatric Urology (ESPU) guidelines state that VCUG should be performed in the evaluation of children with febrile urinary tract infections with the intention to find the etiology (VUR especially) $(2,3)$.

On the other hand, a patient with a recent febrile urinary tract infection (UTI) and a normal VCUG is a challenge for pediatric urologists and nephrologists. Lack of naming a diagnosis after a febrile UTI may put the patient in a position where health care strategies are vague. In this scenario, VUR being the most feared disease to be overlooked, technical insufficiency may be one of the reasons. Therefore, reliability of a single cycle VCUG has been questioned in time and there have been ongoing efforts to set up a standard for the technique of the study (4). Additionally, occult VUR is sometimes attributed to explain this clinical phenomenon(5).

Patients with vesicoureteric reflux that reaches to renal pelvis ( $\geq$ grade 3 also known as dilating VUR) are thought to be more prone to febrile UTI that causes morbidity such as need for hospitalization and renal functional problems (6). The aim of our study is to find the factors that would indicate dilating VUR ( $\geq$ grade 3 ) in patients who undergo a second VCUG after a normal first VCUG.

\section{PATIENTS AND METHODS}

Files of patients who were referred to radiology for VCUG in a children's hospital between 2012 and 2017 were retrospectively reviewed. Patients with more than one VCUG were included. Within the cohort, patients with an abnormal first VCUG (i.e. neuropathic bladder, posterior urethral valves, vesicoureteric relux, and bladder diverticula) were excluded. Factors such as; age, gender, lower urinary tract dysfunction (LUTD), renal scar, recurrent urinary tract infection, abnormal ultrasonography findings (bladder abnormalities/ variable degrees of hydronephrosis), and technical problems (absence of voiding phase) were noted.

Data were analyzed with IBM SPSS 24.0 software. Data was confirmed to be normally distributed using Kolmogorov-Smirnov test, histogram graphics and coefficient of variation analyses. Chi square test was used to compare categorical values while continuous variables were analyzed via Mann-Whitney U test. A p value of $<0.05$ was considered statistically significant in all comparisons.

\section{RESULTS}

A total of 25 patients were found to have met inclusion criteria (19 girls, 6 boys; mean age $6 \pm 3$ years). Median time period between the two VCUGs were 12 months (range1-72 months). VUR was detected in 11 patients, while dilating VUR was discovered in 7. Among those, 6 patients had bilateral disease. Table 1 summarizes statistical analysis of all factors investigated. Only recurrent UTI was found to be associated with dilating VUR in the second VCUG $(p=0,049)$. Interestingly, VUR was not detected in cases that were performed after a first VCUG with inadequate technique. An attempt was made to identify a predictive factor however logistic regression analysis was inconclusive due to small number of patients.

\section{DISCUSSION}

VCUG is the gold standard method in the search of vesicoureteral reflux (1). It is especially important in the evaluation of a child who had a febrile urinary tract infection $(2,3)$. There is no doubt in requesting a VCUG, however, there is huge difference in performing it (7). Therefore, accuracy of VCUG may not be the same worldwide. Recently, a consensus statement was published to reduce discrepancies between clinics (4). Important components included are reducing radiation exposure, proper catheterization, obtaining voiding images and last but not the least cyclic filling of the bladder. Disregarding any of those

Table 1. Factors That Would Indicate Dilating VUR in Patients With a Normal Prior VCUG.

\begin{tabular}{|c|c|c|c|}
\hline & Dilating VUR(n) & No Dilating VUR(n) & $\mathbf{p}$ \\
\hline Female & $9(\% 47.4)$ & $10(\% 52.6)$ & 0.661 \\
\hline Male & $2(\% 33.3)$ & $4(\% 66.7)$ & \\
\hline Febrile UTI & $7(\% 70)$ & $3(\% 30)$ & 0.049 \\
\hline Renal Scar + & $8(\% 50)$ & $8(\% 50)$ & 0.677 \\
\hline Unilateral Hydronephrosis & $7(\% 58.3)$ & $5(\% 41.7)$ & 0.165 \\
\hline Increased Bladder Wall Thickness in US & $3(\% 60)$ & $2(\% 40)$ & 0.623 \\
\hline Bladder Trabeculation in First VCUG & $2(\% 66.7)$ & $1(\% 33.3)$ & 0.565 \\
\hline Proximal Ureter Dilation in First VCUG & $2(\% 66.7)$ & $1(\% 33.3)$ & 0.565 \\
\hline
\end{tabular}

VCUG: Voiding cystourethrography, UTI: Urinary Tract Infection, VUR: Vesicoureteric Reflux 
important steps may result in an inadequate study and incomplete evaluation and moreover misdiagnosis. In our study, \%28 of patients showed dilating VUR in the second VCUG where the first one was normal. Our results indicate more than a quarter of those patients were misdiagnosed during initial evaluation. Although our study was not designed to address it, we believe that following best clinical practice guidelines to perform VCUG plays an important role.

Children with febrile UTI and normal VCUG are clinical dilemmas. Managements of these patients are challenging and hence there has been no clear data on this subset of patients. However, those patients are believed to be prone to another episode of febrile UTI (8). Our study revealed that recurrent urinary tract infection is the only parameter that is associated with dilating VUR in the second VCUG. It has been suggested that positional instillation of contrast method might be beneficial in identifying those patients with a rate of $\% 58.3$ but its clinical impact has not been different from no VUR group (5). Studies have shown that VUR might be present up to $23 \%$ of children undergoing standard VCUG where a third of these are found to be dilating when compared to cyclic VCUG (9). It has also been reported that cyclic VCUG can identify occult VUR in patients over 3 years of age (10). As stated above, following the standard protocol is crucial in performing VCUGs and therefore, should be pursued by clinicians. Interestingly, no VUR has been detected in our study cohort who underwent second VCUG due to technical inadequacy albeit patient numbers are small.

Limitations of our study include of those with a retrospective nature, small number of patients as well as a lack of control group.

\section{CONCLUSION}

Recurrent UTI was shown to be the sole factor is associated with indicate the diagnosis of dilating VUR in the second VCUG. In our study, $28 \%$ patients with a normal first VCUG were shown to have dilating VUR in the second study. Therefore, in recurrent febrile UTI, second VCUG should be considered in patients with a normal previous imaging.

Conflict of interest: Authors declare that there is no conflict of interest between the authors of the article.

Financial conflict of interest: Authors declare that they did not receive any financial support in this study.
Address correspondence to: Muhammet Irfan Donmez, MD, FEBU Konya Training and Research Hospital

Pediatric Urology

Address: Hacı Şaban Mah. Yeni Meram Cad. No: 97 Meram / KONYA

Email: m_irfan83@yahoo.com

Gsm: $+9 \overline{0} 5335717298$

\section{REFERENCES}

1. Lee LC, Lorenzo AJ, Koyle MA. The role of voiding cystourethrography in the investigation of children with urinary tract infections. Can Urol Assoc J 2016;10(5-6):2104.

2. Stein R, Dogan HS, Hoebeke $P$, et al. Urinary tract infections in children: EAU/ESPU guidelines. Eur Urol 2015;67(3):54658.

3. Peters CA, Skoog SJ, Arant BS, et al. Summary of the AUA guideline on management of primary vesicoureteral reflux in children. J Urol 2010;184(3):1134-44.

4. Frimberger D, Mercado-Deane MG, Section On U, et al. Establishing a standard protocol for the voiding cystourethrography. Pediatrics 2016;138(5).

5. Haberal HB, Citamak B, Altan M, et al. Positioning the instillation of contrast cystography: Does it provide any clinical benefit? Urology 2018;112:164-8.

6. Brandstrom $P$, Jodal U, Sillen U, et al. The Swedish reflux trial: Review of a randomized, controlled trial in children with dilating vesicoureteral reflux. J Pediatr Urol 2011;7(6):594600.

7. Lim R. Vesicoureteral reflux and urinary tract infection: Evolving practices and current controversies in pediatric imaging. AJR Am J Roentgenol 2009;192(5):1197-208.

8. Hagerty JA, Maizels M, Cheng EY. The PIC cystogram: Its place in the treatment algorithm of recurrent febrile UTIs. Adv Urol 2008:763620.

9. Papadopoulou F, Efremidis SC, Oiconomou A, et al. Cyclic voiding cystourethrography: Is vesicoureteral reflux missed with standard voiding cystourethrography? Eur Radiol 2002;12(3):666-70.

10. Polito C, Moggio G, La Manna A, et al. Cyclic voiding cystourethrography in the diagnosis of occult vesicoureteric reflux. Pediatr Nephrol 2000;14(1):39-41. 